\title{
パターン認識による赤外吸収スペクトルからのベンゼン 置換様式の推定における波数間隔と領域の検討
}

\author{
田辺 和俊 ${ }^{\circledR}$, 田村 禎夫*
}

(1992 年 5 月 13 日受理)

\section{1 緒言}

赤外吸収スペクトルから未知試料の分子構造を推定す る手段として，条種の官能基の有無を推定するソフトウ エアシステムが市販の赤外分光器の大半には装備されて いる.しかし，それらのソフトウエアシステムにおいて 採用されている官能基の有無を推定する方式はスペクト ルに現れている主要なピークの位置情報のみに基づいて いるため, 一般には多数の官能基が出力され，ユーザー は満足できないことが多い，そのためこれらのシステム について多くのメーカーやユーザーから不満が寄せられ ており, より性能の高い推定システムの開発の要望が高 い. そこで著者はパターン認識手法を用い, 性能の高い 官能基推定システムの開発をめざして研究を行った。

$$
2 \text { 方法 }
$$

赤外吸収スペクトルから官能基を推定するためのパ ターン認識の手法としては様々な方法が考えられるが, 本研究では学習機械方式りを採用した。この方式を赤外 スペクトルからの官能基の有無の推定に適用すると, そ の于:順は次のようになる. 赤外スペクトルの横軸波数 $\boldsymbol{X}\left(x_{1}, x_{2}, \cdots, x_{n}\right)$ に打りるスペクトルの縦軸值のベク トルを $\boldsymbol{Y}\left(y_{1}, y_{2}, \cdots, y_{n}\right)$, それら备点における重みのべ クトルを $\boldsymbol{W}\left(w_{1}, w_{2}, \cdots, w_{n}\right)$ とすると, まず官能基既 知の特定の化合物のスペクトルについてこれら二つのベ クトルの内積

$$
\boldsymbol{P}=\boldsymbol{Y} \cdot \boldsymbol{W}=\sum y_{\mathrm{i}} w_{\mathrm{i}}
$$

を計算し, $\boldsymbol{P} \geqq 0$ ならばその官能基あり, $\boldsymbol{P}<0$ ならば なしと判定する.もしこの判定が違っている場合には式

$$
\boldsymbol{W}^{\prime}=\boldsymbol{W}-2 \boldsymbol{Y}[(\boldsymbol{W} \cdot \boldsymbol{Y}) /(\boldsymbol{Y} \cdot \boldsymbol{Y})]
$$

* [- 業技術院化学技術研究所：305 茨城県つくば市東 1-1
により重みベクトルの修正を行う2)。この修正量が無限 に小さくなるまで以上の操作を繰り返し, 重みベクトル を決定する. 次いで最終的に求められた各波数における 重みベクトルを用いてすべての化合物について官能基の 判定を行った場合の誤答数から認識率を決定する.

以上の方法を用い, 当所で開発中のスペクトルデータ ベースシステム $\mathrm{SDBS}^{3)}$ に集積されているデー夕を利用 して, 赤外スペクトルからの官能基の有無の推定におけ る認識率を求めた。検討した官能基としては, 以下に述 ベるように, データの波数間隔の影響を検討したので, 鋭いピークを示すことが多い官能基の代表としてベンゼ ン環を取り上げた。ベンゼン環には各種の置換様式が考 えられるが, ここでは化合物数の多い置換样式の代表と して, 1 置換, $o-, m-, p-2$ 置換の計 4 種類を取り上げ た.これらの置換様式をもつ化合物の数は Table 1 に 示すようであり，化合物の総数は 675 である。これら のスペクトルデータを用いて, 上述の学習機械方式によ り重みベクトルを決定した。

\section{3 結 果}

波数領域 $4000 \sim 400 \mathrm{~cm}^{-1}$ について波数間隔 $1 \mathrm{~cm}^{-1}$ おきの計 3600 点のデータを用いて, 各種置換様式のべ ンゼン環について決定した重みベクトルを Fig. 1〜4に 示す．重みベクトルのパターンを眺めてみると， 3000 $\mathrm{cm}^{-1}$ 付近の炭素-水素伸縮振動のピークはあまり明確

Table 1 Number of compounds containing each type of substituted benzene

\begin{tabular}{lc}
\hline Type of substitution & Number of compounds \\
\hline Mono-substituted & 231 \\
$o$-Di-substituted & 233 \\
$m$-Di-substituted & 68 \\
$p$-Di-substituted & 179 \\
\hline
\end{tabular}




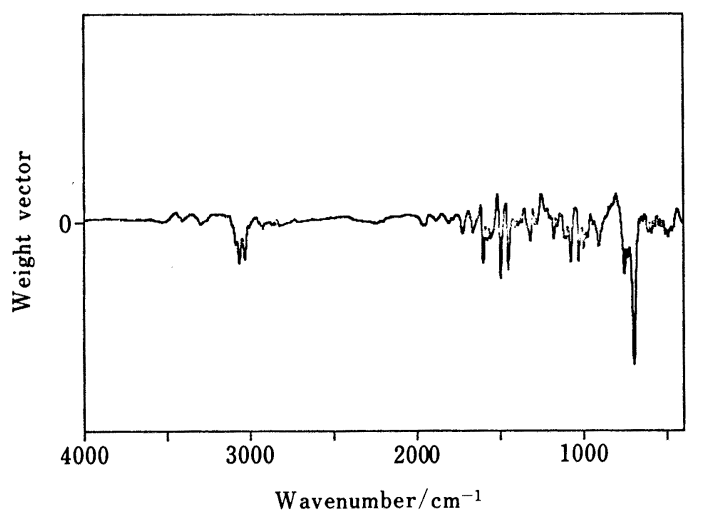

Fig. 1 Weight vector for mono-substituted benzene

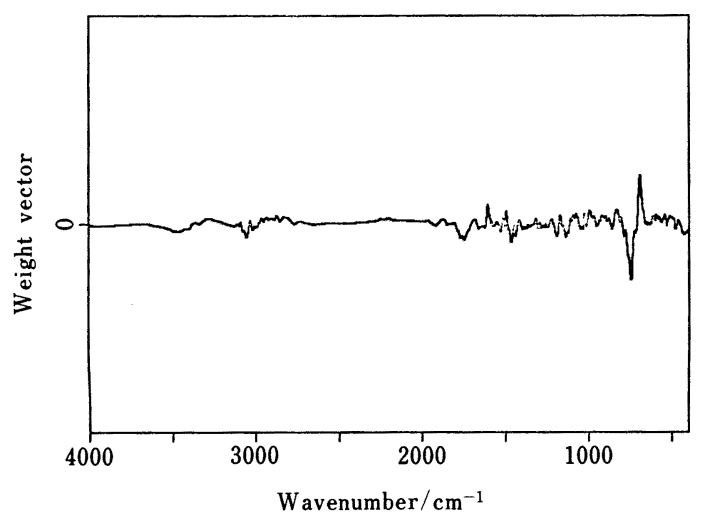

Fig. 2 Weight vector for $o$-di-substituted benzene

には現れていないが，1000〜 $600 \mathrm{~cm}^{-1}$ に現れるベンゼ ン環水素の面外変角振動の特徴的なピークは明確に現れ ている. 従って，ここで決定された重みベクトルはいわ ゆる赤外スペクトルの特性吸収帯にかなりよく対志して いることが分かる.

これらの重みベクトルを用いて判定された官能基の推 定結果を Table 2 に示す。 0 -置換体では認識率が若干低 いが，他の置換様式の場合には $99 \%$ 以上の認識率で判 定できており，実用的にも十分高い性能であることが分 かる.

以上の認識率は横軸波数 3600 点におけるスペクトル データを用いた場合の結果であるが，このデータ数を更 に減らせないかどうかについて次に検討した。デー夕数 を減少させる第 1 の方法は波数間隔を大きくすること である.そこで波数間隔を $1 \mathrm{~cm}^{-1}$ から $32 \mathrm{~cm}^{-1}$ まで

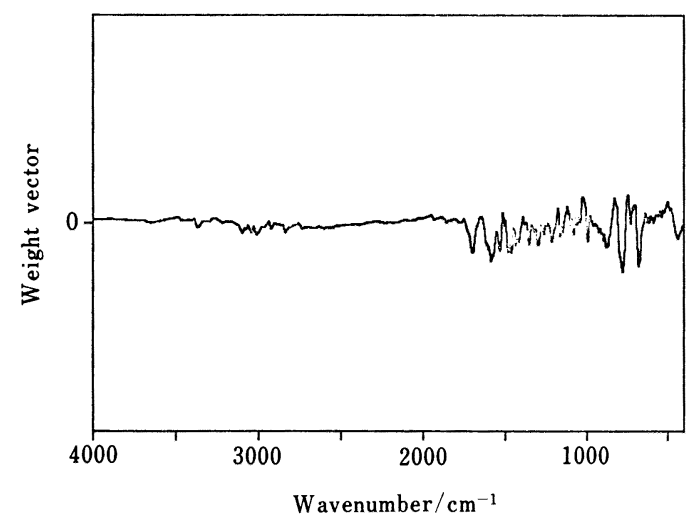

Fig. 3 Weight vector for $m$-di-substituted benzene

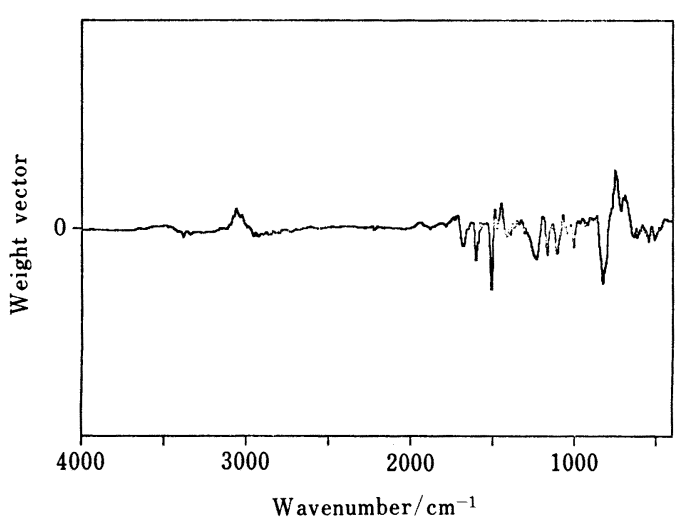

Fig. 4 Weight vector for $p$-di-substituted benzene

拡大して認識率の変化を調べてみた，その結果を Table 2 に示す。当然予想されるように，波数間隔を大きくす ると認識率は徐々に低下し, 認識率を高くするには波数 間隔ができるだけ狭いほうが望ましいことが分かる.

Table 2 の結果からは認識率を低下させない波数間隔と しては $4 \mathrm{~cm}^{-1}$ が限度と考えられる.

デー夕数を減少させる第二.の方法は波数領域を狭める ことである.しかし，Fig. 1〜4の重みべクトルが大き く変化している領域は無視できないと考えられる.そこ でこれらの図の結果を参考にしながらできるだけ影響が 少ないと思われる波数領域を落して認識率の変化を調べ た.その結果, Table 2 に示すように, 波数領域を 1650 ～ $650 \mathrm{~cm}^{-1}$ にとれば認識率はほとんど低下しない ことが分かった。この場合にも当然予想されるように， $o$-置換体の場合の結果に示されているように波数領域を 
Table 2 Accuracy of the estimation of four types of substituted benzene

\begin{tabular}{|c|c|c|c|c|c|}
\hline $\begin{array}{l}\text { Substitution } \\
\text { type }\end{array}$ & $\begin{array}{c}\text { Wavenumber } \\
\text { interval/ } \\
\mathrm{cm}^{-1}\end{array}$ & $\begin{array}{c}\text { Wavenumber } \\
\text { range/ } \\
\mathrm{cm}^{-1}\end{array}$ & $\begin{array}{l}\text { Number of } \\
\text { data points }\end{array}$ & $\begin{array}{c}\text { Number of } \\
\text { errors }\end{array}$ & $\underset{\%}{\text { Accuracy }}$ \\
\hline \multirow[t]{8}{*}{ Mono } & 1.0 & $4000 \sim 400$ & 3600 & 2 & 99.7 \\
\hline & 2.0 & $4000 \sim 400$ & 1800 & 2 & 99.7 \\
\hline & 4.0 & $4000 \sim 400$ & 900 & 2 & 99.7 \\
\hline & 8.0 & $4000 \sim 400$ & 450 & 13 & 98.1 \\
\hline & 16.0 & $4000 \sim 400$ & 225 & 64 & 89.1 \\
\hline & 32.0 & $4000 \sim 400$ & 112 & 125 & 81.5 \\
\hline & 1.0 & $1650 \sim 650$ & 1000 & 2 & 99.7 \\
\hline & 4.0 & $1650 \sim 650$ & 250 & 2 & 99.7 \\
\hline \multirow[t]{3}{*}{$o$-Di } & 1.0 & $4000 \sim 400$ & 3600 & 29 & 95.7 \\
\hline & 1.0 & $1650 \sim 650$ & 1000 & 67 & 90.1 \\
\hline & 4.0 & $1650 \sim 650$ & 250 & 74 & 89.0 \\
\hline \multirow[t]{3}{*}{$m-\mathrm{Di}$} & 1.0 & $4000 \sim 400$ & 3600 & 7 & 99.0 \\
\hline & 1.0 & $1650 \sim 650$ & 1000 & 7 & 99.0 \\
\hline & 4.0 & $1650 \sim 650$ & 250 & 10 & 98.5 \\
\hline \multirow[t]{3}{*}{$p$-Di } & 1.0 & $4000 \sim 400$ & 3600 & 2 & 99.7 \\
\hline & 1.0 & $1650 \sim 650$ & 1000 & 2 & 99.7 \\
\hline & 4.0 & $1650 \sim 650$ & 250 & 2 & 99.7 \\
\hline
\end{tabular}

狭めるとわずかながら認識率は低下しており，認識率を 高くするには波数領域ができるだけ広いほうが望ましい ことが分かる.

以上の結果から認識率を高くするためには波数間隔を できるだけ狭く，波数領域をできるだけ広くすることが 必要であることになる. しかし, 実際の赤外分光器に装 備される官能基推定システムにはコンピュータのメモ リーなどの点からこれらの条件を満たせない場合もある と考えられる. そこでデータ数を 250 点に制限するこ とにして認識率が最も高くなるような波数間隔と波数領 域の設定条件を求めてみた. 250 というデー夕数は市販 の赤外分光器においても最も一般的な条件と考えられる ものである. その結果, Table 2 に示すように, 波数領 域 $1650 \sim 650 \mathrm{~cm}^{-1}$, 波数間隔 $4 \mathrm{~cm}^{-1}$ の条件を選定すれ ば認識率が最高になることが分かった。

これらの設定条件で得られた認識率は波数領域 $4000 \sim 400 \mathrm{~cm}^{-1}$, 波数間隔 $1 \mathrm{~cm}^{-1}$ の場合の認識率とも それほどの差は見られない. 従ってデー夕数が 250 と いう条件がある場合には, ベンゼン環の判定には波数間 隔 $4 \mathrm{~cm}^{-1}$ 及び波数領域 $1650 \sim 650 \mathrm{~cm}^{-1}$ という設定条 件を採用すればよく, その場合の認識率は 0 -置換体で
90\%，その他の置換様式で $99 \%$ 程度になると結論でき る.これらの認識率は十分高い性能であり，以上のよう なパターン認識を利用した官能基推定システムが実用的 な見地からも十分利用可能であると考えられる.

\section{4 結 論}

学習機械方式を用いたパターン認識により赤外スペク トルから官能基の有無を推定する手法を検討した．官能 基としてベンゼン環を選び，スペクトルパターンデータ を用いて学習を行い, 重みベクトルを決定した. その結 果，ほぼ $90 \%$ 以上の認識率でこれらの官能基の有無を 推定できることが分かった。

\section{文献}

1) B. R. Kowalski, P. C. Jurs, T. L. Isenhouer, C. N. Reilley: Anal. Chem., 41, 1945 (1969).

2) 佐々木慎一, 阿部英次, 高橋由雅, 高山千代蔵, 宮 下芳勝: “化学者のためのパターン認識序説”, p. 24 (1984), (東京化学同人).

3) O. Yamamoto, K. Someno, N. Wasada, J. Hiraishi, K. Hayamizu, K. Tanabe, T. Tamura, M. Yanagisawa: Anal. Sci., 4, 233 (1988). 
交

Estimation of substitution form of benzene ring from IR spectra by pattern recognition. Kazutoshi Tanabe and Tadao Tamura (National Chemical Laboratory for Industry, 1-1, Higashi, Tsukuba-shi, Ibaraki 305)

A pattern recognition technique for estimating four types of substituted benzene from IR spectra has been studied using the spectral data of 675 compounds. The accuracy of estimation was evaluated by using a linear learning machine method. It was found that, when there are 250 data points in a computer memory, the wavenumber range of $1650 \sim 650 \mathrm{~cm}^{-1}$ and the wavenumber interval of $4 \mathrm{~cm}^{-1}$ are sufficient, and that the four types of benzene can be estimated with above $90 \%$ accuracy.

(Received May 13, 1992)

\section{Keyword phrases}

functional group estimation; IR data analysis; pattern recognition. 